Józef FIGIEL SDS

(Lublin, KUL)

\title{
POCZĄTKI MONASTYCYZMU W ARMENII (IV-V WIEK)
}

Początków monastycyzmu w Armenii, według pobożnej legendy, należałoby doszukiwać się już w czasach działalności św. Bartłomieja Apostoła, mającego założyć pierwszy żeński monaster zwany „Hokeatz-Vank” z celami przeznaczonymi dla 3 kobiet, którym powierzył opiekę nad ikoną Matki Bożej ${ }^{1}$. Być może, że przekaz ten zawiera autentyczne dane, niemniej jednak sam fakt, iż pochodzi od autora $\mathrm{z}$ VIII/IX wieku, starającego się w ten sposób podkreślić znaczenie tegoż klasztoru-sanktuarium² ${ }^{2}$, budzi szereg wątpliwości. Gdzie więc monastycyzm armeński ma swoje źródła? To zagadnienie było szeroko dyskutowane wśród uczonych i wzniecało liczne kontrowersje. Zdaniem jednych, monastycyzm w Armenii mógł powstać w tym samym czasie, co w Egipcie i Syrii $^{3}$, drudzy twierdzą, że przeniknął w formie życia pustelniczego z Syrii ${ }^{4}$, a jeszcze inni wskazują na Kapadocję i Armenię Mniejszą, a szczególnie na biskupa Sebasty Eustacjusza $(† 378)^{5}$, który wedle świadectwa historyka Sozomena († 450), ,pośród Armeńczyków i Paflagończyków oraz mieszkańców Pontu podobno pierwszy zaczął uprawiać życie mnicha"6. Zdaniem Amadouniego, fakty przekazane przez źródła wskazują, że wpływy syryjskie i greckie

${ }^{1}$ Por. pismo skierowane do księcia Sahaka Ardzrouni, przypisywane Mojżeszowi z Chorenu, w: Moyses Chorensis, Opera, Venetiis 1843, 283-296; cyt. za: M. van Esbroeck, Le naissance du culte de saint Barthélémy, REArm NS 17 (1983) 174; zob. też G. Amadouni, Armeno monachesimo, DIP I 896.

2 Por. Amadouni, Armeno monachesimo, DIP I 896-897.

3 Por. K. Müller, Kirchengeschichte, I, Freiburg in Br. 1892, 211.

${ }^{4}$ Por. E. Ter-Minassiantz, Die armenische Kirche in ihren Beziehungen zu den syrischen Kirchen bis zum Ende des 13. Jahrhunderts nach armenischen und syrischen Quellen bearbeitet, Leipzig 1904, 13; zob. też: tenże, Einige Bemerkungen zu Dr. H. Thopdschians Artikel „Die Anfänge des armenischen Mönchtums", ZKG 25 (1904) 626-630.

${ }^{5}$ Por. F. Loofs, Eustathius von Sebaste und die Chronologie der Basiliusbriefe. Eine patristische Studie, Halle 1898, 54; J. Gribomont, Eustathe de Sébaste, w: DSp IV 1708 i 1712; Ch. Frazee, Anatolian Asceticism in the Fourth Century, ,, The Catholic Historical Review” 68 (1981) 165 i 167.

${ }^{6}$ Por. Sozomenus, HE III 14, PG 67, 1077C, thum. S. Kazikowski (Hermiasz Sozomen, Historia Kościoła, Warszawa 1989), 182. 
były w Armenii mniej więcej takie same, a już przyjęcie chrześcijaństwa (313/314 r.) przez króla Tyrydatesa III i uczynienie go religią państwową na pewno sprzyjało rozwojowi monastycyzmu? ${ }^{7}$. Ten ostatni pogląd wydaje się najbardziej prawdopodobny, skoro wielu uczonych twierdzi, iż chrześcijaństwo miało przenikać do Armenii jednocześnie z dwóch stron: z zachodu (Kapadocja) i z południa (Syria) ${ }^{8}$.

1. Pierwsze wzmianki o życiu monastycznym. Monastycyzm ormiański nie powstał od razu jako określona organizacja religijna, kulturowa i polityczna, ale miał swoje okresy rozwoju9 ${ }^{9}$. Grzegorz Oświeciciel, który doprowadził do chrztu króla Armenii Tyrydatesa III, sam nie zakładał klasztorów, ale, jak informują źródła, miał zamiłowania do życia ascetycznego, a nawet ostatnie lata swego życia miał spędzić jako pustelnik ${ }^{10}$. Później te tradycje będzie kontynuował młodszy syn Grzegorza Arystages, pozostając aż do śmierci w stanie bezżennym, i dlatego też jako pierwszy otrzymał stolicę biskupią po ojcu $^{11}$.

Biograf św. Grzegorza Oświeciciela - Agatangelos, stwierdza, że Grzegorz wracając z Cezarei, po otrzymaniu sakry biskupiej zatrzymał się przez pewien czas w Sebaście u biskupa Piotra, by później wraz z nim udać się do Armenii. Po drodze ,zabrał także ze sobą, kapłanów i mnichów, aby przeznaczyć ich do służby w Kościele Armeńskim" "12. Tę informację przytacza także Zenobiusz

7 Por. Amadouni, Armeno monachesimo, DIP I 880; zob. też I. Dorfmann, Monasteri Armeni, w: Dizionario enciclopedico dell'Oriente Cristiano, ed. E.G. Farrugia, Roma 2000, 499.

${ }^{8}$ Por. M. Ormanian, L'Église arménienne, Paris 1910, 3-5; R. Grousset, L'Histoire de l'Arménie des origines jusqu'à 1071, Paris 1947, 121; D. Próchniak, Początki Kościoła Armeńskiego, „Zeszyty Naukowe Uniwersytetu Jagiellońskiego. Studia Religiologica” 32 (1999) 46; J.P. Mahé, Die Bekehrung Transkaukasiens: Eine Historiographie mit doppelten Boden, w: Die Christianisierung des Kaukasus. Referate des Internationalen Symposions (Wien, 9. bis 12. Dezember 1999), hrsg. W. Seibt, Wien 2002, 112.

9 Por. H. Thopdschian, Die Anfänge des armenischen Mönchtums mit Quellenkritik, ZKG 25 (1904) 16.

10 Por. Agathangelos, Vita Gregorii Illuminatoris, Vs (wersja syryjska) § 292, w: M. van Esbroeck, La résumé syriaque de l'Agathange, AnBol 95 (1977) 355. Na temat wersji językowych Agatangelosa zob. przede wszystkim: G. Garitte, Documents pour l'étude du livre d'Agathange, Città del Vaticano 1946, 1-19, a także M. van Esbroeck, Un nouveau témoin du livre d'Agathange, REArm NS 8 (1971) 14-15; G. Winkler, Our Present Knowledge of the History of Agat'angelos and its Oriental Versions, tamże 14 (1980) 125-135; D. Próchniak, ,Historia Armenii” Agathangelosa jako źródto do poznania chrześcijańskich dziejów Armenii, VoxP 3 (1983) z. 4, 160-175.

${ }^{11}$ Por. Faustus Byzantinus, Historiae III 5, trad. J.B. Émine (Faustus de Byzance, Bibliothéque historique, w: Fragmenta Historicorum Graecorum, V/2: Historicorum Graecorum et Syriorum reliquiae in Armeniorum scriptis servatae, ed. V. Langlois, Parisiis 1884), 212 (dalej: Buzandaran Patmutiwnk). Samo dzieło powstało ok. 470 r. i opisuje wydarzenia z lat 330-387, jednak autor o tym imieniu nie istniał. Nazwa ta jest skutkiem błędnego przetłumaczenia słów Buzandaran Patmutiwnk, które w rzeczywistości znaczą: „historia epiczna”, zob. M. Starowieyski, Faustus z Bizancjum, SWPW 71. 
(Zenob) z Glak, w swojej kronice Historia Taronu ${ }^{13}$, podający się za współpracownika Grzegorza Oświeciciela, ale żyjący w rzeczywistości o wiele później, bo w X/XI wieku ${ }^{14}$, przekazując równocześnie imiona najważniejszych: Antoniego i Kronidę ${ }^{15}$, którzy strzegli relikwii św. Jana Chrzciciela, przywiezionych do Armenii przez św. Grzegorza Oświeciciela, a także imię ucznia pierwszego z nich - Epifaniusza, który stał na czele 40 mnichów ${ }^{16}$. Oprócz Greków spotykamy także działających na terenie Armenii duchownych syryjskich, którzy z powodu niedostatecznej ilości kapłanów, sprawowali liturgię w języku syryjskim, bądź głosili kazania przy pomocy tłumaczy. Najbardziej znaną postacią był wśród nich Daniel Syryjczyk, który według przekazów był uczniem Grzegorza, a następnie został przez niego konsekrowany na biskupa misyjnego dla prowincji Taron ${ }^{17}$. On był właściwym nauczycielem i przewodnikiem życia pustelniczego, sam je zresztą prowadził w pobliżu Hacēac Dracht (ogród jesionów) $^{18}$. Dzięki niemu i jego uczniom prowincja Taron, w której działał, stała się centrum życia monastycznego ${ }^{19}$. Wśród jego uczniów wyróż-

${ }^{12}$ Agathangelos, Vita Gregorii Illuminatoris, Vg $\$ 153$, w: Une nouvelle recension grecque, ed. G. Garitte, w: tegoż, Documents pour l'étude du livre d'Agathange, Città del Vaticano 1946, 95; wersja arabska tegoż w thumaczeniu łacińskim dodaje jeszcze: „zabrał..., bynajmniej nie kilku”, por. Va $§ 141$, Garitte s. 95. K. Stopka (Armenia Christiana. Unionistyczna polityka Konstantynopola $i$ Rzymu a tożsamość chrześcijaństwa ormiańskiego [IV-XV w.], Kraków 2002, s. 29, przypis 70) stwierdza, że użycie określenia „mnisi”, które występuje w tych redakcjach odnośnie towarzyszy Grzegorza, jest na początku IV w. anachronizmem.

${ }_{13}$ Por. Zenobius Glagensis, Historia Tarauni, trad. V. Langlois (Zénob de Glag, Histoire de Daron, w: Fragmenta Historicorum Graecorum, V/2: Historicorum Graecorum et Syriorum reliquiae in Armeniorum scriptis servatae, dz. cyt.), 344.

${ }^{14}$ Por. M. Starowieyski, Zenobiusz z Glak, SWPW 242.

15 Por. Zenobius Glagensis, Historia Tarauni, dz. cyt., s. 337 i 341.

16 Por. tamże, s. 338.

17 Por. Buzandaran Patmutiwnk III 14, Émine s. 224; M.K. Krikorian, Addendum zur Diözesan-Gliederung Armeniens im IV. Jh., w: Die Christianisierung des Kaukasus, dz. cyt., s. 95. E. Ter-Minassiantz dowodzi natomiast (Die armenische Kirche, s. 8; Einige Bemerkungen, s. 627628 ), że Daniel nie był jego uczniem, ale wpływowym syryjskim misjonarzem, którego rola została umniejszona przez tradycję armeńską na rzecz Grzegorza Oświeciciela. Nie można bowiem udokumentować, skąd zjawił się on nagle przy Grzegorzu, trudno też sobie wyobrazić, aby mając 30-35 lat (gdy został biskupem), a nawet więcej, był ciągle jeszcze uczniem, tym bardziej, że wcześniej sam wiele nauczał, nawet w Persji (Buzandaran Patmutiwnk III 14, Émine s. 224). Ponadto słusznie należałoby oczekiwać, że biskupem tej części Armenii, w której jako pierwszej zwyciężyło chrześcijaństwo, powinien zostać Grzegorz. Skoro został nim Daniel, to niewątpliwie jego znaczenie iáwpływy musiały być bardzo duze, a ponadto świadczy to o jego niezależności od Grzegorza Oświeciciela.

${ }^{18}$ Por. Buzandaran Patmutiwnk III 14, Émine s. 225.

${ }^{19} \mathrm{Z}$ czasem powstanie tutaj wiele klasztorów - najbardziej znany wśród nich stanie się klasztor Dwunastu Apostołów, w którym będą znajdować się groby ormiańskich tłumaczy Pisma św. oraz klasztor św. Jana Chrzciciela (Karapeta - św. Poprzednika) z grobami rodu Mamikonianów, por. J.M. Thierry, Répertoire des monastères arméniens, Turnhout 1993, n. 359, s. 68 i n. 368 , s. 70 . 
niali się szczególnie, Szaghita Syryjczyk, który osiedlił się na górze Ariutz $(\text { lew })^{20}$, Epifaniusz, Grek żyjący na górze zwanej Athor Anahta (tron Anahit) ${ }^{21}$ i Armeńczyk Gind, mieszkający w miejscowości Osgig u źródeł Eufratu22. Oni staną się w przyszłości wielkimi filarami monastycyzmu armeńskiego i wsparciem dla działalności Nersesa Wielkiego (353-373). Wśród prekursorów ascetycznego życia był także niewątpliwie biskup Nisibis - Jakub († ok. 338), który według świadectwa autora Buzandaran Patmutiwnk niestrudzenie głosił prawdę Ewangelii w południowej części Armenii Większej, mając nawet, podobnie jak Daniel, władzę czynienia cudów ${ }^{23}$. „Ci mistrzowie ascezy indywidualnej pociągali za sobą rzesze naśladowców, przyciągali tłumy ludzi, szukających rady, uzdrowienia i cudów"24. W ten sposób tworzył się wielki i silny ruch ascetyczny, dzięki któremu katolikos Nerses Wielki będzie mógł założyć wiele klasztorów i instytucji związanych z monastycyzmem ${ }^{25}$.

2. Działalność Nersesa Wielkiego (353-373). Do tej pory rozwijający się w Armenii monastycyzm występował przede wszystkim w formie anachoretyzmu i nie posiadał ściśle określonych ram organizacyjnych. „Nerses Wielki jest tym przedstawicielem Kościoła Armeńskiego w IV wieku, który nadał anachoretyzmowi określoną organizację, a życie pustelnicze przekształcił w kierunku wspólnotowego życia, gdy sformułował zasadę, że dzieło Bożej pracy jest lepsze, niż samotne życie na pustyni" ${ }^{26}$. W prostej linii pochodził z rodu Grzegorza Oświeciciela, jego dziadek Husik (341-347) był czwartym z kolei katolikosem Armenii ${ }^{27}$. Jeszcze w dzieciństwie został wysłany do Cezarei Kapadockiej, aby się kształcić ${ }^{28}$. Tam z pewnością duże wrażenie zrobiła na nim naukowa i monastyczna działalność św. Bazylego Wielkiego ${ }^{29}$. Poznał szereg instytucji, które przejmie ${ }^{30}$ i w przyszłości zacznie wprowadzać w swoim kra-

${ }^{20}$ Por. Buzandaran Patmutiwnk V 25, Émine s. 291.

${ }^{21}$ Por. tamże. Anahit należała do najważniejszych postaci armeńskiego panteonu i utożsamiana była z grecką Artemidą, zob. D. Próchniak, Artašat i Dvin - dwie stolice Armenii, w: Sympozja Kazimierskie poświęcone kulturze świata późnego antyku i wczesnego chrześcijaństwa, II, Lublin 2001,129.

${ }^{22}$ Por. Buzandaran Patmutiwnk VI 16, Émine s. 310.

23 Por. tamże III 10, Émine s. 218. Tradycje życia ascetycznego wśród biskupów związanych z Armenią, kontynuuje też późniejszy biskup Konstantynopola Attyk, por. Socrates, HE VI 20.

${ }^{24}$ Por. Stopka, dz. cyt., s. 42.

25 Por. Thopdschian, art. cyt., s. 19.

26 Tamże; por. też N.G. Garsö̈an, L'Église arménienne et le grand schisme d'Orient, CSCO 574, Subsidia 100, Lovanii 1999, 439-440.

${ }^{27}$ Por. Buzandaran Patmutiwnk IV 3, Émine s. 236.

${ }^{28}$ Por. tamze.

${ }^{29}$ Por. Thopdschian, art. cyt., s. 21. Na temat związków Nersesa z Bazylim Wielkim zob. N.G. Garsoïan, Nersēs le Grand, Basile de Césarée et Eustathe de Sébasthe, REArm NS 17 (1983) 145-169.

${ }^{30}$ Por. Moyses Chorensis, Historia Armeniae, trans. R.W. Thomson (Moses Khorenatsi, History of the Armenians, London 1978), 274. 
ju. Synod w Asztiszat, zwołany w 365 roku $^{31}$, przyczynił się m.in. do realizacji tych zadań. Jego zaś znaczenie polegało przede wszystkim na zredagowaniu szeregu kanonów, które miały służyć reorganizacji Kościoła Armeńskiego i wyeliminowaniu pozostałości zwyczajów pogańskich ${ }^{32}$. To wtedy powstały też liczne placówki charytatywne: szpitale, hospicja, leprozoria i przytułki. Zdaniem Garsoïan, były to instytucje, które, w przeciwieństwie do tych zakładanych przez Bazylego Wielkiego, miały określoną specjalizację, a ponadto powstawały nie tylko w miastach, lecz także w wioskach, a nawet w odludnych miejscach ${ }^{33}$. Pieczę nad nimi sprawowali diakoni i przede wszystkim biskupi ${ }^{34}$. Rezultatem synodu było też powstanie licznych klasztorów, które Nerses zakładał przy pomocy Epifaniusza, Szaghity i Ginda ${ }^{35}$, wspomnianych wcześniej uczniów Daniela Syryjczyka. Dzięki jego staraniom w Armenii powstało wiele szkół (wardapetarany) ${ }^{36}$, w których nauczyciele (wardapeci) kształcili przyszłych mnichów, mając do dyspozycji bogato zaopatrzone w literaturę grecką i syryjską biblioteki ${ }^{37}$. Z czasem staną się one częścią klasztorów.

Najwięcej informacji na temat działalności Nersesa przekazuje nam autor Buzandaran Patmutiwnk, który jest pod wrażeniem jego osobowości. Pisze, że pomnożył on liczbę mnichów i kościołów na wioskach i na pustyniach ${ }^{38}$, a klasztory polecił otaczać murami dla bezpieczeństwa mnichów i mniszek ${ }^{39}$. Ich rozwój uległ zahamowaniu, gdy władzę sprawował król Pap (368-374), który prawdopodobnie otruł katolikosa Nersesa ${ }^{40}$. Jego dzieła zostały wówczas zniszczone, mnichów siłą wcielano do wojska, a mniszki przymuszano nawet do prostytucji ${ }^{41}$. Na skutek tych prześladowań rozpoczęły się masowe migracje do

${ }^{31}$ Por. Buzandaran Patmutiwnk IV 4, Émine s. 239; M.K. Krikorian, The Formation of Canon Law of the Armenian Church, w: Die Christianisierung des Kaukasus, s. 102-103.

${ }^{32}$ Por. A.S. Atiya, Historia Kościołów wschodnich, tłum. E. Balicka, Warszawa 1978, 278.

33 Por. Garsoïan, Nersēs le Grand..., s. 158-159.

${ }^{34}$ Według Garsoïan nie ma jednak przekonywujących dowodów ich przynależności do stanu mniszego, por. tamże, s. 161.

35 Mojżesz z Chorenu wymienia także imię Efrema, por. Historia Armeniae, III 20, Thomson s. 275

${ }^{36}$ Por. Buzandaran Patmutiwnk IV 4, Émine s. 240

37 Więcej na ten temat por. R.W. Thomson, ,Vardapet” in the Early Armenian Church, ,Le Muséon” 75 (1962) 367-384.

${ }^{38}$ Por. Buzandaran Patmutiwnk IV 4, Émine s. 240.

39 Por. tamże, V 31, Émine s. 294.

40 Por. tamże V 24, Émine s. 290-291; Moyses Chorensis, Historia Armeniae, III 38, Thomson s. 299. Polityka króla Papa zorientowana była w stronę Persji, dlatego działalność Nersesa, inspirowana przez grecki Kościół, była negatywnie postrzegana na dworze perskim, por. Amadouni, Armeno monachesimo, DIP I 883. K. Stopka (dz. cyt., s. 44) dodaje, że do śmierci Nersesa mogła też przyczynić się jego niezłomność w obronie dogmatu nicejskiego, ponieważ nie chciał ulegać naciskom ariańskich cesarzy, aby przyjąć arianizm, co też miało być sprawdzianem lojalności Armenii wobec Cesarstwa.

${ }^{41}$ Por. Buzandaran Patmutiwnk V 31, Émine s. 294. Zdaniem K. Stopki (dz. cyt., s. 36, przypis 22) ,nie wszystkie przedsięwzięcia króla Papa miały charakter antychrześcijański. Usuwały jedynie 
tych prowincji, w których władzę królewską ograniczała potężna arystokracja. I znów widzimy rozproszonych uczniów Daniela, którzy wędrowali na czele grup mniszych. Epifaniusz udał się w kierunku prowincji Sofeny i tam nawracał pogan, zakładając klasztory, m.in. nad rzeką Mamuszegh, gdzie gromadzili się rozproszeni mnisi, a nawet zbudował kościół w miejscowości Tigranocerta, w którym regularnie sprawowano Mszę świętą ${ }^{42}$. Szaghita skierował się na południe od Taronu, do prowincji Korduk ${ }^{43}$. Trzeciego ze znanych nam mnichów - Ginda, spotykamy u źródeł Eufratu, już jako przełożonego wielu klasztorów, mającego licznych podwładnych, który nie tylko nawracał pogan, ale też zarządzał klasztorami ${ }^{44}$. Działania podjęte przez króla Papa przyniosły więc odwrotny od zamierzonego skutek. Monastycyzm jeszcze bardziej rozprzestrzenił się po Armenii jako zorganizowana instytucja, niosąc światło wiary nawet do najbardziej oddalonych zakątków i umacniając w wierze armeńskich chrześcijan, wciąż jeszcze głęboko związanych z pogaństwem. Warto podkreślić również to, że w monastycznej szkole Nersesa wychowało się wiele wybitnych postaci z historii Armenii, do których niewątpliwie należy m.in. Sahak Wielki, późniejszy katolikos oraz Mesrop, twórca alfabetu ormiańskiego ${ }^{45}$.

3. Działalność św. Mesropa Masztoca (361-440). Trudno przecenić jego znaczenie dla monastycyzmu, Kościoła i szeroko pojętej kultury Armenii. Jako wychowanek Nersesa Wielkiego ${ }^{46}$, znający biegle język grecki, syryjski i perski, kształcił się także w Bizancjum i Antiochiii ${ }^{47}$. Po powrocie do Armenii pracował początkowo w kancelarii królewskiej, ale pod wpływem wydarzeń politycznych (podział Armenii w 387 r. między Persję i Cesarstwo Rzymskie), a także zachętom swojego wujka Sahaka, katolikosa Armenii (387439), porzucił służbę świecką, przyjął święcenia kapłańskie, a następnie oddał się ascezie ${ }^{48}$. Mojżesz z Chorenu informuje, że Mesrop przystał do grupy mnichów Sahaka, który „miał 60 uczniów na wzór spoudaioi w stolicy, zawsze mu towarzyszących, którzy nosili włosiennicę, żelazny pas i nie mieli żadnych butów. Razem z nimi nieustannie przestrzegał reguły, na wzór tych, którzy żyją na pustyni i troszczył się o nasz kraj, jak ci, którzy przebywają w świecie" ${ }^{49}$.

zjawiska niekorzystne dla państwa". Takim mogła być m.in. ucieczka do klasztorów z obawy przed wcieleniem do wojska.

42 Por. Buzandaran Patmutiwnk V 27-28, Émine s. 292-293.

43 Por. tamże V 26, Émine s. 292.

44 Por. tamże VI 15, Émine s. 310.

45 Por. Moyses Chorensis, Historia Armeniae III 47 i 49, Thomson s. 309 i 313.

46 Por. tamże III 47, Thomson s. 309.

${ }^{47}$ Por. Amadouni, Armeno monachesimo, DIP I 884.

${ }^{48}$ Por. Koriunus, Vita Mesropi § 23, tłum. G. Winkler (Koriwn, Die Geschichte über das Leben und Sterben des seligen Mannes, des hl. Vardapet Mašt ${ }^{c} \mathrm{c}^{c}$, unseres Übersetzers, OCA 245, Roma 1994), 97 (dalej: Koriunus I).

${ }^{49}$ Por. Historia Armeniae III 49, Thomson s. 314. 
Inny historyk - Łazarz z Parp - powie, że Mesrop pojawił się w klasztorze $\mathrm{z}$ wieloma mnichami, a następnie podjął życie ascetyczne, w którym wyraźnie celował, mieszkając na pustkowiu w jaskiniach, w wielu miejscach, wraz $\mathrm{z}$ innymi świętymi mnichami i miłującymi modlitwę braćmi ${ }^{50}$.

Ten styl życia pozyskał mu wielu naśladowców, z którymi rozpoczął ewangelizację w południowo-wschodniej części Armenii nad rzeką Araks (prowincja Gołt $^{\mathrm{c}} \mathrm{n}$ ). W trakcie tej działalności doszedł do wniosku, że misja ta odniesie skutek, tylko wtedy, gdy Pismo św. stanie się zrozumiałe dla ludności. Dlatego, mając poparcie króla Wramszapuha i katolikosa Sahaka, postanowił stworzyć alfabet armeński. To, co nie udało się Danielowi Syryjczykowi ${ }^{51}$, stało się udziałem Mesropa. Po wielu próbach alfabet ujrzał wreszcie światło dzienne na terenie Syrii - w Edessie, a jego wzory kaligraficzne wykonał Rufin z Samosaty $^{52}$. Było to niewątpliwie największe osiągnięcie Mesropa (ok. 404 r.). Od tej pory chrystianizacja Armenii stała się kwestią czasu. W klasztorach powstawały szkoły, które nie tylko kształciły mnichów, ale zajmowały się także tłumaczeniem Pisma świętego, liturgicznych tekstów i dzieł Ojców Kościoła ${ }^{53}$. To wszystko działo się dzięki wsparciu i wydatnej pomocy katolikosa Sahaka $(387-439)^{54}$, który wspólnie z Mesropem wysyła uczniów do Edessy i Konstantynopola. Stamtąd sprowadzili dzieła pisarzy chrześcijańskich i tekst Peshitty, która zostanie poprawiona na podstawie Septuaginty i dzieł Ojców Kościoła ${ }^{55}$. Biograf Koriun twierdzi, że w drugiej fazie jego ewangelizacji w prowincji Gołt $\mathrm{c}$ Mesrop ,,zakładał w każdej miejscowości wspólnoty świętych mnichów” 56 , żyjących „w miejscach zamieszkałych i bezludnych, na równinach i w górach, w pieczarach i w zamkniętych klasztorach"57, którzy włączali się w pracę przekładania na język armeński Pisma Świętego, tekstów liturgicznych i dzieł pisarzy patrystycznych. Dla tej pracy poświęcił całą swoją energię. Zmarł kilka miesięcy po śmierci swojego przyjaciela - katolikosa Sahaka Wielkiego $(\text { ok. } 440 \text { r. })^{58}$. Efektem jego działalności był wzrost liczby mnichów i klasztorów

${ }^{50}$ Por. Lazarus Parpecinus, Historia Armeniae I 10, w: C. Sanspeur, Le fragment de l'Histoire de Lazare de Ṕarpi, découvert dans le Ms. 1 de Jérusalem, REArm NS 10 (1973-1974) 8.

51 Por. Koriunus I § 31-42, Winkler s. 98-99.

52 Por. tamże I § 43-52, Winkler s. 99-101.

${ }^{53}$ Na temat armeńskich tłumaczeń Pisma św. i dzieł Ojców Kościoła por. np. J.M. Alexanian, The Armenian Gospel Text from the fifth through the fourteenth Centuries, w: Medieval Armenian Culture, ed. T. Samuelian - M.E. Stone, Chico 1983, 381-394, S. Lyonnet, Les origines de la version arménienne et le Diatessaron, Roma 1950; J.P. Mahé, L'Arménie et les Pères de l'Église: histoire et mode d'emploi ( $V^{e}-X I I^{e}$ siècles), w: La Documentation patristique, ed. J.C. Fredouille - R.M. Roberge, Québec - Paris 1995, 167-179.

${ }^{54}$ Por. Moyses Chorensis, Historia Armeniae III 60, Thomson s. 334.

55 Por. Koriunus I § 142-144, Winkler s. 112; Moyses Chorensis, Historia Armeniae III 61, Thomson s. 335-336.

${ }^{56}$ Koriunus I § 76, Winkler s. 104.

57 Tamże I § 149, Winkler s. 113. 
do tego stopnia, że można mówić o swoistej ekspansji monastycyzmu. Wzbudziło to nawet zaniepokojenie perskiego władcy Jazdegerda II (439-457), prześladowcy Kościoła armeńskiego, dla którego monastycyzm wspierający rozwój chrześcijaństwa, stanowił niewątpliwie zagrożenie dla jego koncepcji ideologicznej unifikacji państwa poprzez mazdeizm. Dlatego też dążył do powstrzymania tego ruchu, co wyrażało się m.in. w takich zarządzeniach, jak nakaz zamiany stroju zakonnego na świecki, zarówno dla mnichów, jak i mniszek ${ }^{59}$. Nie przyniosły one jednak spodziewanych rezultatów, co więcej, monastycyzm umocnił się jeszcze bardziej, a liczba mnichów znacznie wzrosła ${ }^{60}$.

4. Formy życia monastycznego. Monastycyzm armeński, jak zostało to wcześniej powiedziane, miał swoje etapy rozwoju. W pierwszej fazie występował w formie anachoretyzmu, który również i później współistniał z cenobityzmem. Charakterystycznym rysem anachoretów są odejścia na miejsca pustynne, asceza i medytacja spraw Bożych, z powstrzymaniem się od czynnej działalności apostolskiej. „Ich apostolat polegał i koncentrował się na dawaniu

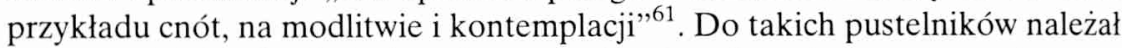
m.in. Daniel Syryjczyk, który „do zamieszkania wybierał niezamieszkałe przez człowieka góry, żywił się korzeniami i trawą, a jako ubranie służył mu tylko płaszcz ze skóry i sandały, nie używał też nigdy laski" ${ }^{62}$. Niemniej jednak żywo interesował się życiem wspólnoty chrześcijańskiej i potrafił opuszczać miejsca pustynne, aby w pobliskich miejscowościach czynić dobre uczynki i dokonywać cudów, które, jak stwierdza autor Buzandaran Patmutiwnk, trudno opisać słowami ${ }^{63}$. Nawet wtedy, gdy był już biskupem, mieszkał w jamie wykopanej w ziemi, skąd często dokonywał obchodów swojej diecezji ${ }^{64}$. Wokół niego gromadzili się uczniowie i w ten sposób tworzyły się pierwsze kolonie mnichów, które z czasem staną się zaczątkami klasztorów. Jednak anachoretyzm

${ }^{58}$ Por. tamże I § 172, Winkler s. 117; Moyses Chorensis, Historia Armeniae III 67, Thomson s. 348 .

59 Por. Eliseus Vardapetus, Historia Vardani, trad. V. Langlois (Élisée Vartabed, Histoire de Vartan et de la guerre des Arméniens, w: tenże, Collection des historiens anciens et modernes de l'Arménie, t. 2, Paris 1869), 199.

${ }^{60}$ Kronikarz klasztoru św. Jana Chrzciciela z Klag - Jan Mamikonian, podający się za pisarza z VII wieku, żyjący jednak o wiele później (por. Starowieyski, Zenobiusz z Glak, SWPW 242), podaje, że liczba mnichów tego klasztoru w 1. poł. VII w. miała wynosić ok. 500, zob. Historia Tarauni tłum. J.R. Émine (Jean Mamigonien, Histoire de Daron, w: Fragmenta Historicorum Graecorum, V/2: Historicorum Graecorum et Syriorum reliquiae in Armeniorum scriptis servatae, dz. cyt.), 362-363. Dzięki pracy Mesropa i Sahaka również chrześcijaństwo w Armenii nie osłabło, nawet mimo prześladowań Jazdegerda II, por. Stopka, dz. cyt., s. 55.

61 Amadouni, Armeno monachesimo, DIP 890.

62 Buzandaran Patmutiwnk III 14, Émine s. 225.

${ }^{63}$ Por. tamże.

${ }^{64}$ Por. tamże. 
nie zaniknie nawet wtedy, gdy zaczną powstawać wspólnoty cenobityczne. $\mathrm{Z}$ reguły każdy monaster dawał możliwość realizacji powołania anachorety, ponieważ posiadał wewnątrz swych murów pustelnie ${ }^{65}$. Sam Mesrop, który jest założycielem wielu klasztorów, podejmował różne umartwienia na wzór anachoretów, które się wyrażały, jak informuje jego biograf ${ }^{66}$, m.in. samotnym życiem w górach, przebywaniem w ciemnych pomieszczeniach, pokutnym odzieniem, legowiskiem na twardej ziemi, spożywaniem bezmięsnego pożywienia, a nawet zupełnym wstrzymywaniem się od pokarmów i napojów. Wiele razy przedkładał też nocny spoczynek nad długie modlitewne czuwania. Tej kategorii mnichów nie brakowało nigdy w Armenii, choć sam cenobityzm był już w pełnym w rozkwicie ${ }^{67}$.

Sława wybitnych anachoretów przyciągała wielu naśladowców i tak rodził się powoli cenobityzm. Już Daniel Syryjczyk miał swoich kontynuatorów, a ci z kolei skupiali wokół siebie licznych uczniów, którzy zakładali klasztory, a jeden spośród nich - Gind, miał nawet ułożyć regułę dla monastycznych wspólnot ${ }^{68}$. W ten sposób uwidacznia się troska o przyszłość monastycyzmu, która jeszcze bardziej przebija z działalności Nersesa, a następnie Sahaka i Mesropa. Oni nie tylko zakładali kolejne klasztory, ale także kształcili mnichów przygotowując ich do pracy w szkołach klasztornych (wardapetarany) i na polu duszpasterskim. Dla Mesropa ważna była również formacja duchowa przyszłych mnichów. Dlatego też, jak pisze Koriun ${ }^{69}$, wskazuje im siebie samego jako wzór mnicha, a od czasu do czasu bierze niektórych uczniów z klasztorów i idzie z nimi w góry. Tam mieszkali w jaskiniach, żywiąc się ziołami i poddając różnym umartwieniom, w myśl słów św. Pawła: „Ilekroć dla Chrystusa jestem słaby, tylekroć staję się mocny" (2 Kor 12,10). Przez uduchowiony śpiew uczyli się wychwalać i oddawać cześć Bogu, i słuchali nauk Mesropa, który wdrażał ich do umiejętności rozumnego czytania Pisma świętego, umacniając ich w powołaniu przez pobudzające nauki ${ }^{70}$. I w ten sposób przebywali

${ }^{65}$ Por. Amadouni, Armeno monachesimo, DIP I 888.

${ }^{66}$ Por. Koriunus I § 24, Winkler s. 97.

${ }^{67}$ Pisarz z V wieku Elizeusz tak opisuje anachoretów swojego czasu: „mężczyźni, już w wieku młodzieńczym oddzieleni od domu rodzinnego, aby poświecić się pobożności, którzy osiedlili się w miejscach pustynnych po 2 lub 3, w oddzielnych celach uczynionych przez nich samych, z pryczami ze słomy na ziemi, osłonione murami i słabymi dachami, chroniącymi przed zimnem w zimie i promieniami słońca w lecie", por. De monachis, w: Opera, Venezia 1859, 159-165, cyt. za: Amadouni, Armeno monachesimo, DIP I 888. Anachoretyzm w poszczególnych przypadkach będzie istniał poza klasztorami aż do połowy XIX wieku, zob. Thopdschian s. 19.

68 Por. Buzandaran Patmutiwnk VI 15, Émine s. 310. Nie znaczy to jednak, że w IV-wiecznej Armenii istniało zorganizowane życie cenobityczne. Na te informacje należy raczej patrzeć przez pryzmat niejasnych i anachronicznych tekstów armeńskich z V i późniejszych wieków, por. R.W. Thomson, Syrian Christianity and the Conversion of Armenia, w: Die Christinisierung des Kaukasus, s. 162, przypis 20.

${ }^{69}$ Por. Koriunus I § 149-152, Winkler s. 113-114. 
wiele dni na pustkowiu, do czasu, aż Mesrop nie został wezwany przez kapłanów, aby spieszyć na pomoc okolicznym kościołom w różnych potrzebach ${ }^{71}$.

Cenobityzm armeński stara się więc jednoczyć doskonałość chrześcijańską $z$ ewangelizacją i apostolatem na wzór reguły, którą św. Bazyli nadawał swoim klasztorom w Kapadocji ${ }^{72}$. Istnieją też wzmianki ${ }^{73}$ pozwalające przypuszczać, że cenobityzm armeński był łączony ze stylem życia mnichów akojmetów, założonych nad Bosforem przez św. Aleksandra (350-430), nazywanych tak dla nieustannego śpiewania w chórze psalmów ${ }^{74}$. Była to właśnie wspomniana wcześniej grupa mnichów skupionych wokół Sahaka Wielkiego, do których przystał też Mesrop ${ }^{75}$. Podobieństwo do akojmetów wyrażało się w praktykowaniu wspólnego życia, boskiej doksologii, studium Pisma św. w celu przepowiadania Słowa Bożego, i podejmowaniem inicjatyw apostolskich ${ }^{76}$.

Działalność apostolska klasztorów w znacznym stopniu przyczyniła się do chrystianizacji Armenii. Już anachoreci przez podejmowany styl życia byli ewangelizatorami najodleglejszych zakątków kraju, jego utrwalenie jednak jest zasługą przede wszystkim monasterów, które były wyposażone w szkoły obsługujące miasta i wioski. Tutaj także wytworzy się klasa mnichów przeznaczonych do posługi słowa i dla apostolatu, tzw. hieromonachów ${ }^{77}$, którzy byli celibatariuszami i posiadali jakiś stopień święceń kapłańskich, po skończonych zaś studiach kościelnych osiągali władzę stopnia wardapet ${ }^{78}$. Powierzano im nauczanie ludzi i wychowanie młodego pokolenia, szczególnie tych, którzy mieli zamiar wstąpić do klasztoru. Później wykonywali też, oprócz nauczania, inne funkcje. Była to unikalna cecha armeńskiej edukacji, która nie miała

${ }^{70}$ Por. tamże. Inna recenzja dzieła Koriuna dodaje, że Mesrop zachęcał mnichów, aby „żyli na wzór jego pobożnego trudu, który wyrażał się nie tylko przez mowę i nauczanie, lecz także przez działanie, jako osobisty przykład dla mnichów, w tym, że zmagał się z sobą nieustannym postem i modlitwą, nocnymi czuwaniami i płaczem, pokorą i łagodnością, i jako celibatariusz, aby być zawsze mężnym i stanowczym wákonfrontacji z wrogiem”, zob. Koriunus II § 149, Winkler s. 131.

71 Por. tamże.

72 Por. Amadouni, Armeno monachesimo, DIP I 887; Thopdschian, art. cyt., s. 23-24.

${ }^{73}$ Por. Moyses Chorensis III 49, Thomson s. 314.

${ }^{74}$ Por. J.M. Szymusiak, Akemeci, EK I 234-235.

75 Por. przypis 49.

76 Por. Amadouni, Armeno monachesimo, DIP I 887. Thopdschian uważa, że ten rodzaj życia nie mógł być jednak praktykowany w Armenii, ponieważ pierwsze wzmianki o akojmetach, pochodzące od Sokratesa i Sozomena, wskazują na 440 rok jako datę ich założenia, tymczasem Sahak zmarł w 439 roku. Ponadto wydaje się niemożliwe, aby był też uczniem Aleksandra - założyciela akojmetów, skoro pełnił obowiązki katolikosa i był zajęty różnymi problemami Kościoła Armeńskiego, zob. art. cyt., s. 26-27.

${ }^{77} \mathrm{Na}$ temat historycznej roli hieromonachów w Armenii zob. G. Amadouni, Le rôle historique des hiéromoines arméniens, w: Il monachesimo orientale, OCA 153, Roma 1958, 279-305.

78 Por. Amadouni, Armeno monachesimo, DIP I 890. Na temat rozwoju tego terminu w Kościele Armeńskim zob. R. Thomson, Vardapet in the Early Armenian Church, „Le Muséon" 75 (1962) 367-384. 
odpowiednika w innych wschodnich krajach chrześcijańskich ${ }^{79}$. Dzięki nim też powstała w Armenii wspaniała literatura i kwitła sztuka miniaturyzatorska i kopiowania kodeksów ${ }^{80}$. Do ich zadań należała również pomoc biskupom w charakterze wikariuszy, kanonistów i penitencjarzy, spośród nich także wybierano kandydatów do biskupstwa ${ }^{81}$. Ich zasługi dla kultury armeńskiej były więc znaczące i niepodważalne.

Reasumując można stwierdzić, że monastycyzm był związany organicznie z historią chrześcijańskiej Armenii. Do jego rozwoju niewątpliwie przyczynił się fakt przyjęcia chrztu przez króla Tyrydatesa III, niemniej jednak na terytorium Armenii przenikał już wcześniej z terenów Syrii i Kapadocji. Początkowo występował jako anachoretyzm, który charakteryzował się podejmowaniem różnych form ascezy, niekiedy bardzo surowej. Ten styl życia sam w sobie był formą działalności ewangelizacyjnej wśród pogańskiej ludności, poprzez ukazywanie wzoru cnót chrześcijańskich, i przyciągał też wielu naśladowców, którzy z czasem organizowali się w grupy mnisze. W ten sposób rodziła się nowa forma monastycyzmu - cenobityzm, oparty na wspólnym życiu, przy czym anachoretyzm zawsze miał swoich zwolenników. Pierwsze klasztory powstały w prowincji Taron już na początku IV wieku. Nowe oblicze monastycyzmowi nadał katolikos Nerses Wielki, ukierunkowując go na działalność charytatywną i edukacyjną. Wtedy powstało też wiele męskich i żeńskich wspólnot monastycznych opartych na regule św. Bazylego Wielkiego. Z czasem stały się one centrami kulturalnymi, w których znajdowały się szkoły, obsługujące poszczególne miejscowości, a także akademie monastyczne (wardapetarany), które kształcily przyszłych nauczycieli (wardapetów). Tę kulturalną działalność monastycyzmu jeszcze bardziej rozszerzył Mesrop i katolikos Sahak Wielki, którzy w klasztorach zakładali skryptoria i ośrodki translatorskie, w których tłumaczono Pismo święte, teksty liturgiczne, dzieła Ojców Kościoła, a także pisma świeckich autorów klasycznych. Tam też powstawało wiele dzieł w rodzimym języku, dzięki stworzeniu przez Mesropa alfabetu armeńskiego. W następstwie tej działalności „literatura armeńska jest, obok literatury syryjskiej, najbogatszą literaturą wczesnochrześcijańskiego Wschodu, zarówno pod względem ilości dzieł oryginalnych, jak i przekładów z literatury greckiej, a później i z literatury lacińskiej”82. Klasztory staną się więc ośrodkami „tworzenia

\footnotetext{
${ }^{79}$ Por. Thomson, Vardapet in the Early Armenian Church, s. 367.

80 Zdaniem R. Thomsona historia terminu vardapet $w$ jego pełni rozwiniętej formie jest praktycznie synonimiczna $\mathrm{z}$ historią armeńskiej nauki, por. tamże, s. 384.

${ }^{81}$ Por. Amadouni, Armeno monachesimo, DIP I 892.

${ }^{82}$ M. Starowieyski, Armeńska literatura patrystyczna, SWPW 23.
} 
i przechowywania dóbr kulturowych, zaś w okresie ciemności, który nastąpi po ostatecznym upadku państwowości armeńskiej, dzięki nim przede wszystkim przetrwa pamięć narodu" 83 .

\section{DIE ANFÄNGE DES MÖNCHTUMS IN ARMENIEN}

\section{(Zusammenfassung)}

Das armenische Mönchtum steht im organischen Zusammenhang mit der Geschichte des christlichen Armenien. Zu seiner Entwicklung hat bestimmt der Empfang der Taufe vom König Tiridates III beigetragen. Es drang aber schon früher in seiner ursprünglichen Gestalt von Syrien und Kappadozien aus in Armenien ein. Anfangs hat es als Einsiedlerleben erschienen, das sich die strenge Askese charakterisiert hat. Dieses Leben war ein Muster christlicher Tugenden und deshalb brachte es heidnischen Bevölkerung zum echten Glaube und allenthalben Imitatoren warb, die tratten zusammen. In dieser Weise entstand neue Form des Mönchtums - Zönobitentum, das sich auf gemeinsames Leben gründete. Die ersten Klöstern sind schon im 4. Jh. in Provinz Taron eingerichtet worden, das Einsidlerleben aber bestand weiter neben ihnen. Nerses der Große hat dem Mönchtum eine bestimmte Richtung gegeben, wenn er es zu der Karitativs- und Erziehungstätigkeit geleitet hat. Er hat die mönchischen und Wohltätigskeitinstitutionen des Basilius der Große in Armenien eingeführt. Damals haben viele Nonnen- und Mönchklöster entstanden, in denen Schulen für die Bevölkerung und für Mönche waren. Diese Tätigkeit ist von Mesrop und Sahak der Größe verbreitet worden. Sie bildeten in den Klostern ganze Scharen der Skriptor und der Übersetzer. Wenn Mesrop das armenische Alphabet erfunden hatte, begann man mit den Übersetzungen den Heiligen Schrift, Werken der Kirchenväter, liturgischen und kanonischen Texten. Man übersetzte auch manche Bücher der klassischen Schriftsteller. Infolgedessen hat auch die armenische Nationalliteratur entstanden, die eine der reichsten Literatur der christlichen Orient ist. Armenisches Mönchtum hat also den Grund zu der künftigen Kultur so fest gelegt.

${ }^{83}$ A. Mandalian, Wstęp, w: Grzegorz z Nareku, Księga śpiewów żałobliwych, tłum. A. Mandalian, Warszawa 1990, 27-28. 